\title{
Author Correction: Mature Andean forests as globally important carbon sinks and future carbon refuges
}

Alvaro Duque (D), Miguel A. Peña, Francisco Cuesta, Sebastián González-Caro, Peter Kennedy, Oliver L. Phillips (D), Marco Calderón-Loor (1D, Cecilia Blundo (1), Julieta Carilla (1D, Leslie Cayola, William Farfán-Ríos (1), Alfredo Fuentes, Ricardo Grau, Jürgen Homeier (1D, María I. Loza-Rivera, Yadvinder Malhi (B), Agustina Malizia (D), Lucio Malizia, Johanna A. Martínez-Villa (D), Jonathan A. Myers (D), Oriana Osinaga-Acosta, Manuel Peralvo, Esteban Pinto, Sassan Saatchi, Miles Silman, J. Sebastián Tello, Andrea Terán-Valdez \& Kenneth J. Feeley (D)

Correction to: Nature Communications https://doi.org/10.1038/s41467-021-22459-8; Published online 09 April 2019.

The numbering in the reference list was incorrect in the original article through numbers 29 to 65 . This has now been amended.

Published online: 08 June 2021

\footnotetext{
(c) Open Access This article is licensed under a Creative Commons Attribution 4.0 International License, which permits use, sharing, adaptation, distribution and reproduction in any medium or format, as long as you give appropriate credit to the original author(s) and the source, provide a link to the Creative Commons license, and indicate if changes were made. The images or other third party material in this article are included in the article's Creative Commons license, unless indicated otherwise in a credit line to the material. If material is not included in the article's Creative Commons license and your intended use is not permitted by statutory regulation or exceeds the permitted use, you will need to obtain permission directly from the copyright holder. To view a copy of this license, visit http://creativecommons.org/licenses/by/4.0/.
}

(C) The Author(s) 2021 